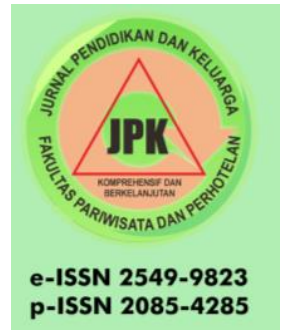

JURNAL PENDIDIKAN DAN KELUARGA

Vol. 11 No. 02, 2019 Page 74-85

DOI: : https://doi.org/10.24036/jpk/vol11-iss02

available at http://jpk.ppj.unp.ac.id/index.php/jpk/index

\title{
PENGARUH PENGGUNAAN BUAH ALPUKAT DAN VIRGIN COCONUT OIL (VCO) TERHADAP PERAWATAN RAMBUT RONTOK
}

\author{
Syanaz Rizka ${ }^{1}$, Yuliana ${ }^{2}$ \\ 1,2 Program Studi Pendidikan Tata Rias dan Kecantikan, Jurusan Tata Rias dan \\ Kecantikan, Fakultas Pariwisata dan Perhotelan, Universitas Negeri Padang. \\ Email: rsyannaz@gmail.com
}

DOI: https://doi.org/10.24036/jpk/vol11-iss02/613

Accepted: 2019-10-29

URL:http://jpk.ppj.unp.ac.id/index.php/jpk/article/view/613

\begin{abstract}
Excessive hair loss will cause baldness. It can will influence someone's confidence. that is why, hair loss treatment is needed to be done. One of them is by using avocados and VCO. They have good function to stimulate hair growth and make them healthier. This study aims to analyze the effect of avocados and VCO toward hair loss treatment. The research was done by observing the mount of hair loss everyday. this study was conducted with a quasi-experimental method with a quasi exsperiment to explain the influence of using avocados and VCO on the treatment of hair loss. The research subjects were a collection of women who lived in the Parak Laweh area of Lubuk Begalung subdistrict which improved hair loss at the level of 40-100 strands per day. The sample in this study amounted to 12 people used by the technique of taking documentation and interviews. This study consisted of 4 different groups, namely the control group (X0), experimental group 1 (X1), experimental group 2 (X2), and experimental group 3 (X3).The data gathered is primary data. It is directly taken from samples that fill in the research format provided. Data analysis using analysis of variance (anava) and continued with Duncan test, the results of this study show a significant difference in the indicator of the amount of hair detached from the scalp with the number of strands of hair falling after treatment in the control group (X0) (80.50), experimental group 1 (X1) (60.50), experimental group 2 (X2) (58.83) and experimental group 3 (X3) (58.67). So it can be said that for the indicator of the amount of hair loss in the experimental group did not show a statistically significant difference, but there was a significant difference in the treatment of hair loss in the control group.
\end{abstract}

Keywords: hair loss, avocados, VCO

\section{Pendahuluan}

Rambut mempunyai peran penting dalam kehidupan manusia, baik pria maupun wanita. Rambut berfungsi untuk menunjang penampilan dan menambah kecantikan, juga berfungsi sebagai penghangat dan pelindung kulit kepala (Rostamailis dkk, 2009). Rambut sehat memiliki ciri-ciri tebal, bewarna hitam, berkilau, tidak kusut, dan tidak 
rontok menjadi kebutuhan semua orang. Namun demikian tidak semua orang memiliki rambut sehat, karena dapat dipengaruhi oleh berbagai faktor yang dapat menyebabkan rambut menjadi tidak sehat ( Rostamailis dkk, 2009:15). Rambut yang tidak sehat memiliki ciri-ciri antara lain rambut kusam atau tidak berkilau, rambut kusut atau sulit diatur, rambut berminyak, rambut beruban bagi orang yang masih muda, rambut bercabang, rambut mudah patah dan rambut rontok.

Ciri rambut tidak sehat yang tidak diharapkan oleh kebanyakan orang yaitu rambut rontok. Rambut rontok yang dialami dapat membuat seseorang menjadi kurang rasa percaya diri untuk tampil di depan publik. Menurut Tranggono (2007:36) menjelaskan bahwa: "rambut rontok merupakan hal yang wajar terjadi pada manusia selama rambut rontok tersebut terjadi sekitar 40-100 helai tiap harinya". Rambut kepala yang panjang akan lebih banyak rontoknya di bandingkan rambut kepala yang pendek di karenakan rambut kepala yang panjang lebih berat hingga mengakibatkan tarikan pada rambut yang berlebihan.

Penyebab rambut rontok dapat disebabkan oleh stress, mengkonsumsi obatobatan, ketidakseimbangan hormon, menopause, pemakaian zat kimia yang berlebihan pada kulit kepala dan rambut, ketombe, salah dalam penggunaan shampoo, pemakaian catok dan hairdryer yang terlalu sering (Rostamailis dkk, 2008:45). Rambut rontok biasanya dialami oleh seseorang yang memiliki jenis rambut kering. Menurut Dalimarta(1998:9) "hal tersebut dikarenakan penyakit defisiensi atau kekurangan vitamin B kompleks, vitamin C, zat besi, zinc (seng) dan silica. Berdasarkan pendapat diatas apabila kerontokan rambut sudah melebihi dari 40-100 perhari, maka harus cepat di waspadai agar kondisi rambut tersebut tidak bertambah rontok yang bisa mengakibatkan kebotakan (alopecia).

Adapun cara mengatasi rambut rontok adalah dengan dapat melakukan perawatan dari dalam maupun dari luar. Perawatan dari dalam yaitu mengkonsumsi makanan atau minuman yang mengandung semua zat-zat atau vitamin seperti dengan buah-buahan dan sayur-sayuran. Sedangkan perawatan dari luar dapat dilakukan sehari-hari, berkala dengan menggunakan kosmetik yang sesuai untuk perawatan yang dilakukan. Pada prinsipnya kosmetik terkelompok kepada beberap jenis, seperti dikemukakan Rostamailis dkk (2005: 14-15) yaitu a) kosmetik tradisional, yang dapat dibuat sendiri dengan bahan alami, b) kosmetik semi tradisional, berbahan alami ditambah bahanbahan pengawet, c) kosmetik modern, yang diproduksi secara pabrik (laboratorium). Menurut Tranggono (2007:5) menyatakan bahwa "shampoo adalah salah satu kosmetik pembersih rambut dan kulit kepala dari segala macam kotoran, baik yang berupa debu, sel-sel yang mudah mati dan sebagainya". Seseorang yang mengalami rambut rontok harus berhati-hati dalam memilih kosmetik yang tepat dan benar. Karena kalau tidak tepat dalam memilih kosmetik akan membuat rambut bertambah rontok.

Cara alternatif dalam menggunakan kosmetika tersebut dapat digantikan dengan menggunakan bahan kosmetika alami yang mengandung kandungan yang hampir sama dengan bahan kosmetika pabrik agar memilik manfaat yang tanpa menimbulkan efek samping. Sejalan dengan hal tersebut, konsep hidup back to nature (kembali ke alam) mulai diminati dan di dukung pula denga melimpahnya kekayaan alam di Indonesia. Bpahan-bahan alami tersebut berfungsi penyubur rambut dan mencegah kerontokan rambut seperti jeruk nipis, daun seledri, buah alpukat dan minyak kepala murni (VCO). Menurut Rahmadani, Hayatunnufus dan Yuliana(2012) menyatakan bahwa "jeruk nipis telah di uji dan diteliti secara kimia memiliki unsur senyawa yang dapat menggantikan fungsi obat kimiawi untuk mengatasi ketombe dan rambut rontok. Lisnawati, Rostamailis dan Yuliana (2013) juga menjelaskan bahwa " daun seledri juga telah diuji dan diteliti untuk rambut kering dan rontok yang banyak mengandung minyak asri dan flavonoid. 
Andi (2013) menyatakan" buah alpukat merupakan buah yang sangat bergizi, mengandung 3-30 persen minyak dengan komposisi yang sama dengan minyak zaitun dan mengandung vitamin B. Buah alpukat juga mengandung asam lemak tak jenuh tunggal (asam oleat). Asam oleat berfungsi memperlambat kerontokan dan mempercepat pertumbuhan rambut. Sedangkan minyak kelapa murni (VCO) memiliki kandungan asam laurat tinggi $45-55 \%$ dan $7 \%$ asam kapirat. Kedua asam tersebut merupakan asam lemak jenuh rantai yang mudah dimtabolisme dan sifat antimikroba sehingga dapat miningkatkan kekebalan tubuh dan mampu mengurangi kehilangan protein pada rambut rusak maupun rambut tidak rusak sehingga memberikan penampilan rambut yang sehat dan tidak kering (Alamsyah, 2005). Minyak kelapa murni (VCO) juga bisa sebagai penyeburan rambut yang stabil dan dapat mengurangi kerontokan pada rambut. Jelaslah dalam hal ini menyatakan bahwa: penggunaan buah alpukat dan minyak kelapa murni (VCO) dapat bermanfaat untuk bahan kosmetika alami yang berfungsi untuk memperlambat kerontokan dan sebagai penyuburan rambut yang sehat.

Berdasarkan hal diatas penulis bermaksud menggunakan hair mask alami dari bahan buah alpukat dan minyak kelapa murni (VCO) sebagai bahan hairmask yang akan penulis gunakan untuk membantu mengurangi rambut rontok. Hair mask merupakan perawatan dengan menambah nutrisi pada rambut dan kulit kepala, mengurangi stress pada rambut serta kulit kepala dan memiliki tujuan antara lain (a) mengobati kerusakan rambut yang terjadi pada lapisan korteks, (b) mengurangi stress pada rambut serta kulit kepala, (c) menutrisikan rambut kering, (d) meningkatkan elastisitas pada batang rambut, (e) menguatkan akar rambut (Nurlaili, 2013:14). Simons (2004:33) menyatakan yaitu "Lakukanlah masker rambut (hairmask) secara rutin 2 kali dalam 7 hari".

Berdasarkan observasi dan wawancara yang telah peneliti lakuakan sebelumnya pada tanggal 30 Maret 2018 kepada sekelompok wanita di lingkungan Parak Laweh Kecamatan Lubuk Begalung yang berusia 18-25 tahun, penulis menemukan masalah rambut rontok. Sebanyak 12 orang mengeluh rambut rontok lebih dari 40-100 helai perhari pada saat rambut disisir. Dari hasil observasi yang penulis lakukan ditemui fakta bahwa permasalahan rambut rontok merupakan permasalahan yang paling banyak dikeluhkan oleh wanita, pada umumnya mereka menyatakan bahwa: rambut rontok sangat mengganggu dalam meresahkan akibat kerontokan dalam jumlah cukup besar setiap harinya mencapai lebih kurang 80 helai.

Selanjutnya apa saja yang mengakibatkan rambut rontok secara berlebihan dan wanita di lingkungan Parak Laweh Kecamatan Lubuk Begalung menyatakan bahwa di akibatkan oleh beberapa hal seperti, perawatan rambut yang menggunakan kosmetika yang mengandung bahan kimia, penggunaan hijab yang terlalu lama dan suka mengganti-ganti pola rambut dengan pemakaian alat catok, curly, hairdryer dan lainlain.

Berdasarkan latar belakang dan pengamatan peneliti menunjukkan bahwa banyaknya permasalahan rambut rontok yang dialami oleh wanita di lingkungan Parak Laweh Kecamatan Lubuk Begalung. Hal ini dikarenakan belum dilakukan tindakan dalam mengatasi masalah rambut rontok menggunakan bahan alami seperti buah alpukan dan minyak kelapa murni (VCO). Oleh karena itu tujuan penelitian bermaksud adalah a) untuk menganalisis pengaruh rambut rontok tanpa menggunakan alpukat dan minyak kelapa murni (VCO) yang di amati dari jumlah helaian rambut yang tertarik. b) untuk menganalisis pengaruh penggunaan buah alpukat untuk perawatan rambut rontok yang di amati dari jumlah helaian rambut yang di tarik setelah perlakuan. c) untuk menganalisis pengaruh penggunaan minyak kelapa murni (VCO) untuk perawatan rambut rontok yang dapat di amati dari jumlah helaian rambut yang di tarik setelah perlakuan. d) untuk menganalisis pengaruh penggunaan buah alpukat dan minyak kelapa 
murni (VCO) secara bersama untuk perawatan rambut rontok yang dapat di amati dari jumlah helaian rambut yang di tarik setelah perlakuan.

\section{Metode}

Penelitian ini dilakukan dengan metode quasi eksperimen. Metode quasi eksperimen merupakan penelitian yang mendekati metode eksperimen sungguhan (Lufri, 2007:62). Desain penelitian yang akan digunakan yaitu Nonequivalent Control Group Desaign yaitu menjelaskan pengaruh penggunaan buah alpukat dan vigin coconut oil (VCO) terhadap perawatan rambut rontok. Sampel dalam penelitian ini dibagi menjadi 4 kelompok yaitu kontrol $\left(X_{0}\right)$, kelompok eksperimen $1\left(X_{1}\right)$, kelompok eksperimen $2\left(X_{2}\right)$ dan kelompok eksperimen $3\left(X_{3}\right)$. Dalam pertanyaan ini penulis ingin melihat pengaruh pemanfaatan buah alpukat dan virgin coconut oil (VCO) untuk mengatasi rambut rontok. Objek penelitian yang akan digunakan dalam penelitian ini yaitu rambut yang ada di kepala dan jumlah helaian rambut yang rontok setelah perlakuan. Teknik Pengambilan data pada penelitian ini merupakan data primer. Data primer adalah data yang diambil langsung tanpa perentara dari sumbernya.

\section{Teknik Analisis Data \\ Uji persyaratan analisis \\ Uji Normalitas}

Uji normalitas digunakan untuk mengetahui apakah populasi data berdistribusi normal atau tidak. Dalam penelitian ini digunakan uji One Sample Kolmogrov-Smirnov dengan menggunakan taraf signifikasi lebih besar dari 5\% atau 0.05 (Santoso, 2009:342). Data dikatakan normal jika skor sig $>0,05$.

\section{Uji Homogenitas}

Uji homogenitas adalah penguji yang digunakan untuk mengetahui apakah varians kelompok bersifat homogeny. Asumsi yang mendasari dalam analisis varian adalah bahwa varian dari populasi adalah sama. Sebagai kriteria $F_{\text {hitung }}>F_{\text {tabel }}$ maka kedua varian data berasal dari kelompok yang tidak homogen. Untuk itu digunakan uji statistik dengan program SPSS versi 21.00. Kriteria pengambilan keputusan ditetapkan sebagai berikut: jika nilai signifikan hitung besar $\alpha$ (alpha) 0,05 . Kriteria pengambilan keputusan ditetapkan sebagai berikut: jika nilai signifikan pada levence statistic>signifikan $\alpha$ $(0,05)$ maka data dapat dikatakan memiliki varians yang homogeny pada taraf signifikan 0,05 .

\section{Uji Anova}

Anava dapat digunakan untuk menganalisa sejumlah sampel dengan jumlah data yang sama pada tiap-tiap kelompok sampel atau dengan jumlah data yang berbeda. Menggunakan bantuan SPSS versi 21.00, dan dilanjutkan dengan uji duncan untuk melihat perbedaan pada kelompok perlakuan perbedaan.

Tabel 1. Rumus analisis Varians

\begin{tabular}{|c|c|c|}
\hline Sumber Varians & $\begin{array}{l}\text { Derajat Bebas } \\
\text { (DB) }\end{array}$ & Kuadrat Mean (MK) \\
\hline Kelompok (K) & $i K k=\sum \frac{\left(\sum K K\right)^{2}}{n k}-\frac{\left(\sum K r\right) d b_{l-\Sigma-1}}{N}$ & 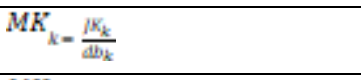 \\
\hline Dalam (d) & $\not K_{P}=J K \|_{p}-J K_{p}$ & 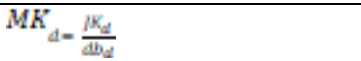 \\
\hline Total $(\mathrm{T})$ & $f K_{\mathrm{r}}=\sum N r^{2}-\frac{\left(\sum N r\right)^{2}}{N} \quad d b_{r=\bar{N}=1}$ & \\
\hline
\end{tabular}

Sumber: Arikunto (2010) 


\section{Syanaz Rizka ${ }^{1}$, Yuliana ${ }^{2}$}

\section{Keterangan:}

Nk : Jumlah subjek dalam kelompok

$\mathrm{K}$ : Banyak kelompok

$\mathrm{N}$ : Jumlah subjek seluruhnya

$\frac{\left[(x)^{2}\right.}{N}=$ Faktor Kolerasi yang muncul berkali-kali

\section{Uji Duncan}

Dapat digunakan untuk menguji perbedaan diantara semua pasangan perlakuan yang mungkin tanpa memperhatikan jumlah perlakuan.

Berikut rumus Uji Duncan:

Duncan : $\mathrm{t} \mathrm{a} / 2 ; \sqrt[d \mathrm{dru}]{\frac{2 x r s}{r}}$

Keterangan:

KTS : Kuadrat tengah sisa

dbs : Derajat bebas sisa

$\mathrm{r} \quad$ : Banyaknya ulangan

\section{Hasil dan Pembahasan}

Deskripsi Data Perawatan Rambut Rontok Tanpa Menggunakan Buah Alpukat Dan

VCO Pada Kelompok Kontrol $\left(X_{0}\right)$

Berdasarkan dokumentasi data dapat diberi penilaian dengan melihat perubahan yang terjadi pada perawatan rambut rontok berdasarkan kondisi awal yang akan dideskripsikan dalam tabel distribusi rata-rata perawatan rambut rontok pada kelompok kontrol seperti di bawah ini:

Table 1 Skor tingkat keberhasilan dalam perawatan rambut rontok pada kelompok kontrol (X0)

\begin{tabular}{|c|c|c|c|c|c|c|c|c|c|c|c|c|c|c|}
\hline \multirow{2}{*}{ No } & \multirow{2}{*}{$\begin{array}{l}\text { Nama } \\
\text { Sampel }\end{array}$} & \multicolumn{3}{|c|}{ Penilaian Ke- } & \multirow[b]{2}{*}{ P3 } & \multirow[b]{2}{*}{ P4 } & \multirow[b]{2}{*}{ P5 } & \multirow[b]{2}{*}{ P6 } & \multirow[b]{2}{*}{ P7 } & \multirow[b]{2}{*}{ P8 } & \multirow[b]{2}{*}{ P9 } & \multirow[b]{2}{*}{ P10 } & \multirow[b]{2}{*}{ P11 } & \multirow[b]{2}{*}{ P12 } \\
\hline & & Pretest & P1 & P2 & & & & & & & & & & \\
\hline 1 & $\mathbb{X}_{0.1}$ & 85 & 81 & 83 & 80 & & & & 82 & 84 & 80 & 78 & 80 & 83 \\
\hline 2 & $x_{0.2}$ & 85 & 83 & 80 & 82 & 84 & 80 & 78 & 82 & 80 & 76 & 79 & 82 & 80 \\
\hline 3 & $\mathbb{X}_{0.3}$ & 88 & 84 & 80 & 83 & 81 & 79 & 77 & 75 & 78 & 82 & 80 & 78 & 80 \\
\hline & Jumlah & 258 & 248 & 243 & 245 & 243 & 235 & 234 & 239 & 242 & 238 & 237 & 240 & 243 \\
\hline & Rata-rata & 86 & 82.7 & 81 & 81.7 & 81 & 78.3 & 78 & 79.7 & 80.7 & 79.3 & 79 & 80 & 81 \\
\hline
\end{tabular}


Berdasarkan tabel 1 di atas dapat diuraikan bahwa penilaian perawatan rambut rontok tanpa penggunaan masker rambut buah alpukat sebagai perawatan rambut rontok dapat diuraikan sesuai dengan indikatornya yaitu kerontokan rambut secara rata-rata menunjukkan skor 86 pada saat pretest, perlakuan 1 rata-rata 82,7, perlakuan 2 rata-rata 81 , perlakuan 3 rata-rata 81,7, perlakuan 4 rata-rata 81, perlakuan 5 menunjukkan ratarata 78,3, perlakuan 6 rata-rata 78, perlakuan 7 rata-rata 79,7, perlakuan 8 rata-rata 80,7, perlakuan 9 rata-rata 79,3, sedangkan pada perlakuan 10 menunjukkan rata-rata 79 dan perlakuan 11 dan 12 rata-rata 80-81.

\section{Deskripsi Data Perawatan Rambut Rontok Dengan Menggunakan Buah Alpukat ( $X_{1}$ )}

Berdasarkan dokumentasi data dapat diberi penilaian dengan melihat perubahan yang terjadi pada perawatan rambut rontok berdasarkan kondisi awal yang akan di deskripsikan dalam tabel distribusi rata-rata perawatan rambut rontok pada kelompok perlakuan menggunakan buah alpukat seperti di bawah ini:

Table 2 Skor Tingkat Keberhasilan dalam Perawatan Rambut Rontok pada Kelompok Eksperimen 1 (X1)



Berdasarkan Tabel 2 diatas dapat diuraikan bahwa penilaian perawatan rambut rontok menggunakan masker rambut buah alpukat dengan frekuensi 2 kali 7 hari dapat diuraikan sesuai dengan indikatornya yaitu jumlah rambut yang rontok dari kepala secara rata-rata menunjukkan skor 86,7 , pada perlakuan 1 skor rata-rata 84 , pada perlakuan 2 skor rata-rata 81,3, pada perlakuan 3 skor rata-rata 78, pada perlakuan 4 skor rata-rata 74,3, pada perlakuan 5 skor rata-rata 70,7, pada perlakuan 6 skor rata-rata 66,3 , pada perlakuan 7 skor rata-rata 61,3 , pada perlakuan 8 skor rata-rata 56,7 , pada perlakuan 9 skor rata-rata 49,3, pada perlakuan 10 skor rata-rata 43,7, pada perlakuan 11 skor rata-rata 34,7 dan pada perlakuan 12 skor rata-rata 26,7. Hasil penelitian ini menunjukkan tingkat keberhasilan perawatan rambut rontok menggunakan masker rambut buah alpukat menunjukkan keberhasilan dari saat pretest sampai perlakuan 12 .

\section{Deskripsi Data Perawatan Rambut Rontok Dengan Menggunakan VCO $\left(X_{2}\right)$}

Berdasarkan dokumentasi data dapat diberi penilaian dengan melihat perubahan yang terjadi pada perawatan rambut rontok berdasarkan kondisi awal yang akan dideskripsikan dalam tabel distribusi rata-rata perawatan rambut rontok pada kelompok perlakuan menggunakan VCO seperti di bawah ini: 
Table 3 Skor Tingkat Keberhasilan dalam Perawatan Rambut Rontok pada Kelompok Eksperimen 2 (X2)

\begin{tabular}{|c|c|c|c|c|c|c|c|c|c|c|c|c|c|c|}
\hline \multirow{2}{*}{ No } & \multirow{2}{*}{$\begin{array}{l}\text { Nama } \\
\text { Sampel }\end{array}$} & \multicolumn{3}{|c|}{ Penilaian Ke- } & \multirow[b]{2}{*}{ P3 } & \multirow[b]{2}{*}{$\mathrm{P} 4$} & \multirow[b]{2}{*}{ P5 } & \multirow[b]{2}{*}{ P6 } & \multirow[b]{2}{*}{ P7 } & \multirow[b]{2}{*}{ P8 } & \multirow[b]{2}{*}{ P9 } & \multirow[b]{2}{*}{ P10 } & \multirow[b]{2}{*}{ P11 } & \multirow[b]{2}{*}{ P12 } \\
\hline & & $\begin{array}{l}\text { Pres } \\
\text { test }\end{array}$ & $\mathrm{P} 1$ & P2 & & & & & & & & & & \\
\hline 1 & $\mathbb{X}_{\mathrm{2} .1}$ & 87 & 84 & 81 & 78 & 75 & 70 & 65 & 60 & 54 & 48 & 42 & 35 & 28 \\
\hline 2 & $\mathbb{X}_{\mathrm{z} .2}$ & 86 & 83 & 80 & 76 & 72 & 68 & 63 & 58 & 52 & 46 & 40 & 34 & 28 \\
\hline \multirow[t]{3}{*}{3} & $\mathbb{X}_{\mathrm{2} \cdot 3}$ & 89 & 86 & 83 & 80 & 75 & 69 & 63 & 57 & 51 & 45 & 39 & 32 & 23 \\
\hline & Jumlah & 262 & 253 & 244 & 234 & 222 & 207 & 191 & 175 & 157 & 139 & 121 & 102 & 79 \\
\hline & Rata-rata & 87.3 & 84.3 & 81.3 & 78 & 74 & 69 & 63.7 & 58.3 & 52.3 & 46.3 & 40.3 & 34 & 26.3 \\
\hline
\end{tabular}

Berdasarkan Tabel 3 diatas dapat diuraikan bahwa penilaian perawatan rambut rontok menggunakan masker rambut VCO dengan frekuensi 2 kali 7 hari dapat diuraikan sesuai dengan indikatornya yaitu jumlah rambut yang rontok dari kepala secara rata-rata menunjukkan skor 87,3 , pada perlakuan 1 skor rata-rata 84,3 , pada perlakuan 2 skor rata-rata 81,3 , pada perlakuan 3 skor rata-rata 78, pada perlakuan 4 skor rata-rata 74, pada perlakuan 5 skor rata-rata 69 , pada perlakuan 6 skor rata-rata 63,7 , pada perlakuan 7 skor rata-rata 58,3, pada perlakuan 8 skor rata-rata 52,3, pada perlakuan 9 skor rata-rata 46,3, pada perlakuan 10 skor rata-rata 40,3, pada perlakuan 11 skor rata-rata 34 dan pada perlakuan 12 skor rata-rata 26,3. Hasil penelitian ini menunjukkan tingkat keberhasilan perawatan rambut rontok menggunakan masker VCO menunjukkan keberhasilan dari saat pretest sampai perlakuan 12 .

\section{Deskripsi Data Perawatan Rambut Rontok dengan Menggunakan Buah Alpukat dan VCO}

Berdasarkan dokumentasi data dapat diberi penilaian dengan melihat perubahan yang terjadi pada perawatan rambut rontok berdasarkan kondisi awal yang akan dideskripsikan dalam tabel distribusi rata-rata perawatan rambut rontok pada kelompok perlakuan menggunakan buah alpukat dan VCO seperti di bawah ini:

Table 4 Skor Tingkat Keberhasilan dalam Perawatan Rambut Rontok pada Kelompok Eksperimen 3 (X3)



Berdasarkan tabel diatas dapat diuraikan bahwa penilaian perawatan rambut rontok menggunakan masker rambut buah alpukat dan VCO dengan frekuensi 2 kali 7 hari dapat diuraikan sesuai dengan indikatornya yaitu jumlah rambut yang rontok dari kepala secara rata-rata menunjukkan skor 87 , pada perlakuan 1 skor rata-rata 83,7 , pada perlakuan 2 skor rata-rata 80,3 , pada perlakuan 3 skor rata-rata 77 , pada perlakuan 4 skor rata-rata 72,7 pada perlakuan 5 skor rata-rata 68 , pada perlakuan 6 skor rata-rata 63,3 , pada perlakuan 7 skor rata-rata 58,3 , pada perlakuan 8 skor rata-rata 53, pada perlakuan 9 skor rata-rata 47,3, pada perlakuan 10 skor rata-rata 41, pada perlakuan 11 skor rata-rata 33,7 dan pada perlakuan 12 skor rata-rata 25,7. Hasil penelitian ini (c) (i) This is an open access article distributed under the Creative Commons 4.0 Attribution License, which permits unrestricted use, distribution, and reproduction in any medium, provided the original work is properly cited. @2017 by author and Universitas Negeri Padang. 
menunjukkan tingkat keberhasilan perawatan rambut rontok menggunakan masker buah alpukat dan VCO menunjukkan keberhasilan dari saat pretest sampai perlakuan 12.

\section{Uji Persyaratan Analisis Uji Normalitas}

Uji normalitas dilakukan dengan menggunakan uji Kolmagorof Smirof (Uji K-S). Taraf signifikan yang dipakai sebagai dasar menolak atau menerima keputusan normal atau tidaknya suatu distribusi data adalah 0,05. Normal jika skor Sig>Alpha 0,05. Hasil perhitungan uji normalitas kerontokan rambut dapat dilihat pada tabel berikut ini:

Table 5 Normalitas pada Keempat Kelompok

One-Sample Kolmogorov-Smirnov Test

\begin{tabular}{lll}
\hline & & $\mathrm{y}$ \\
\hline $\mathrm{N}$ & & 12 \\
\hline Normal Parameters $^{\mathrm{a}}$ & Mean & 6.50 \\
\cline { 2 - 3 } & Std. Deviation & 3.606 \\
\hline \multirow{2}{*}{ Most Extreme Differences } & Absolute & .089 \\
\cline { 2 - 3 } & Positive & .089 \\
\cline { 2 - 3 } & Negative & -.089 \\
\hline Kolmogorov-Smirnov Z & & .309 \\
\hline Asymp. Sig. (2-tailed) & 1.000 \\
\hline a. Test distribution is Normal. & \\
\hline
\end{tabular}

Dari tabel di atas dapat dilihat bahwa skor signifikan probabilitas sebesar 1,000. Sedangkan taraf signifikan yang digunakan adalah 0,05. Karena nilai Asymp. Sig (2tailed) lebih besar dari 5\% atau 0,05 maka dinyataka bahwa data berdistribusi normal.

\section{Uji Homogenitas}

Table 6 Uji Homogenitas pada Keempat Kelompok

\begin{tabular}{llll}
\hline \multicolumn{4}{l}{ Test of Homogeneity of Variances } \\
\hline $\mathrm{Y}$ & & & \\
\hline Levene Statistic & df1 & df2 & Sig. \\
\hline 1.259 & 11 & 132 & .255
\end{tabular}

Dari data di atas dapat diketahui bahwa harga levene statistic menunjukan nilai signifikan dengan skor 0,255, angka ini lebih besar dari signifikan $a$ (alpha) 0,05 maka dapat disimpulkan bahwa kelompok data bersifat homogen.

\section{Uji Anava}

Uji selanjutnya menggunakan analisis varians (ANAVA) dengan alfa 5\% untuk mengetahui apakah tiga kelompok perlakuan memiliki beda yang signifikan, dan dilanjutkan dengan Post Hoc Test dengan uji Duncan untuk mengetahui kelompok perlakuan mana yang berbeda. Hasil uji ANAVA perawatan rambut rontok dengan empat perlakuan yang berbeda yaitu sebagai berikut: 
Syanaz Rizka ${ }^{1}$, Yuliana ${ }^{2}$

Table 7 Hasil Analisis Perbandingan (ANOVA)

\begin{tabular}{lllllll}
\hline & Sum of Squares & Df & Mean Square & F hitung & F tabel & Sig. \\
\hline Between Groups & 12221.910 & 11 & 1111.083 & 4.072 & 1.86 & .000 \\
\hline Within Groups & 36017.583 & 132 & 272.860 & & & \\
\hline Total & 48239.493 & 143 & & & \\
\hline
\end{tabular}

Berdasarkan perhitungan ANAVA dapat terlihat bahwa pada kerontokan rambut terdapat $F_{\text {hitung }}(4,072)>F_{\text {tabel }}(1,86)$ yang berarti terdapat pengaruh yang signifikan pada perawatan rambut rontok dari perlakuan yang berbeda terhadap keberhasilan perawatan rambut rontok.

\section{Uji Duncan}

Terdapatnya hasil yang diperoleh dari perawatan rambut rontok dengan perlakuan yang berbeda pada rambut, maka diperlukan uji Duncan untuk melihat perlakuan mana yang berbeda. Hasil uji Duncan yang diperoleh sebagai berikut:

Table 8 Tabel 12. Hasil Analisis Uji Lanjut (Duncan) Indikator Jumlah Rambut Yang Terlepas DariAkarnya Setiap Hari

\begin{tabular}{|c|c|c|c|}
\hline \multicolumn{4}{|c|}{ Skor } \\
\hline \multirow[b]{2}{*}{ Kelompok } & \multirow[b]{2}{*}{$\mathrm{N}$} & \multicolumn{2}{|c|}{ Subset for alpha $=0.05$} \\
\hline & & 1 & 2 \\
\hline $\mathrm{X} 3$ & 12 & 58.67 & \\
\hline $\mathrm{X} 2$ & 12 & 58.83 & \\
\hline $\mathrm{X} 1$ & 12 & 60.50 & \\
\hline $\mathrm{X} 0$ & 12 & & 80.50 \\
\hline Sig. & & .799 & 1.000 \\
\hline
\end{tabular}

Tabel di atas menunjukan pengaruh perlakuan yang berbeda dalam perawatan rambut rontok. Terlihat pada kelompok kontrol $(80,50)$ berbeda signifikan pada kelompok perlakuan menggunakan buah alpukat $(60,50)$, pada kelompok perlakuan menggunakan VCO $(58,83)$ dan pada kelompok perlakuan menggunakan buah alpukat dan VCO $(58,67)$. Dengan demikian dapat dikatakan bahwa untuk indikator jumlah kerontokan rambut pada kelompok eksperimen tidak menunjukkan perbedaan yang signifikan secara statistik, namun terdapat perbedaan yang signifikan terhadap perawatan rambut rontok pada kelompok kontrol.

\section{Pembahasan}

Hasil penelitian ini menunjukkan bahwa tingkat keberhasilan perawatan rambut rontok dengan empat kelompok perlakuan yang berbeda yaitu kelompok kontrol $\left(X_{0}\right)$, kelompok perlakuan perawatan menggunakan buah alpukat $\left(X_{1}\right)$, kelompok perlakuan perawatan menggunakan VCO $\left(X_{2}\right)$ dan kelompok perlakuan perawatan menggunakan buah alpukat dan $\operatorname{VCO}\left(X_{a}\right)$, yang dilakukan dengan Uji Anova terdapat hasil yang signifikan dengan hasil $F_{\text {hitung }}(4,072)>F_{\text {tabel }}(1,86)$. Selanjutnya dilakukan Uji Duncan dengan hasil tidak terdapat perbedaan yang signifikan antara 3 kelompok eksperimen, tetapi terdapat perbedaan yang signifikan terhadap kelompok kontrol.

Menurut Pusponegoro (2002:11), "rambut rontok ialah berkurangnya rambut terminal pada suatu daerah yang seharusnya berambut, dalam bentuk apapun dan

This is an open access article distributed under the Creative Commons 4.0 Attribution License, which permits unrestricted use, distribution, and reproduction in any medium, provided the original work is properly cited. $\odot 2017$ by author and Universitas Negeri Padang. 
dimanapun asal mula terjadinya. Dalam dunia medis atau kedokteran kerontokan rambut ini dikenal dengan sebutan "efluvium". Sedangkan dalam dunia kecantikan bahasa untuk kerontokan rambut ini dikenal dengan hair loss". Tranggono (1992:20) menjelaskan,"rambut rontok (Efluvium) adalah kehilangan rambut terminal dalam bentuk apapun dimanapun, asal mula terjadinya yang berkisar lebih dari 40-100 helai per hari. Dapat terjadi difus atau lokal. Kelainan setempat dapat berupa unifokal atau multifokal. Bila kerontokan ini berlajut dapat terjadi alopecia (kebotakan)". Berdasarkan pendapat Tranggono di atas bila kerontokan rambut sudah melebihi dari 100 helai perhari, maka harus cepat di waspadai agar kondisi rambut tersebut tidak bertambah rontok yang bisa mengakibatkan kebotakan (alopecia).

Pemanfaatan penggunaan masker rambut (hair mask) merupakan salah satu jenis perawatan rambut rontok. Seperti yang dikatakan Nurlaili (2013:14) menjelaskan bahwa," Masker (hair mask) merupakan perawatan dengan menambah nutrisi pada rambut dan kulit kepala, mengurangi stress pada rambut serta kulit kepala dan memiliki tujuan antara lain (a) mengobati kerusakan rambut yang terjadi pada lapisan korteks, (b) mengurangi stress pada rambut serta kulit kepala, (c) memelihara kelembaban rambut, (d) menutrisi rambut kering, (e) memulihkan serta memperbaiki kondisi rambut, (f) mengangkat sel-sel kulit mati di kulit kepala merangsang pertumbuhan rambut, (g) meningkatkan elastisitas pada batang rambut, (h) menguatkan akar rambut".

Terlihat pada penelitian bahwa terjadinya peningkatan keberhasilan jumlah kerontokan rambut setelah diberi perawatan menggunakan masker rambut (hair mask) buah alpukat dan VCO. Hal ini dapat disebabkan kandungan bahan kimia yang terdapat pada buah alpukat dan VCO. Buah alpukat merupakan buah yang sangat bergizi, mengandung 3-30 persen minyak dengan komposisi yang sama dengan minyak zaitun dan banyak mengandung vitamin B (Andi,2013). Buah alpukat juga mengandung asam lemak tak jenuh tunggal (asam oleat). Asam oleat berfungsi memperlambat kerontokan dan mempercepat pertumbuhan rambut. Sedangkan Virgin Coconut Oil (VCO) atau minyak kelapa murni tersusun atas senyawa organik campuran ester dan gelisol, asam lemak. Menurut hasil penelitian asam lemak tidak jenuh merupakan unsur-unsur esensial untuk perawatan kulit, termasuk kulit kepala karena dapat bekerja sebagai pelembut (emolient) pada kulit kepala dan rambut. Minyak kelapa mampu mengurangi kehilangan protein pada rambut rusak maupun rambut yang tidak rusak sehingga memberikan penampilan rambut yang sehat dan tidak kering (Almsyah, 2005). Minyak kelapa murni atau VCO juga bisa sebagai penyeburan rambut yang stabil dan dapat mengurangi kerontokan pada rambut.

Berdasarkan analisis yang telah dilakukan, maka perawatan rambut rontok tanpa pemanfaatan buah alpukat dan VCO pada kelompok kontrol yang dinilai dari jumlah rambut yang rontok tidak menunjukan perubahan yang signifikan pada perawatan rambut rontok, yaitu skor jumlah rambut rontok tidak ada perubahan dari perlakuan pertama hingga perlakuan terakhir dengan skor rata-rata 80,50. pada perawatan rambut rontok menggunakan buah alpukat yang dinilai dari jumlah kerontokan pada rambut dapat dinilai dari hasil deskripsi data yang menyatakan skor tertinggi diperoleh dihari terakhir perlakuan yaitu pada skor rata-rata 60,50, pada perawatan rambut rontok menggunakan VCO yang dinilai dari jumlah kerontokan pada rambut dapat dinilai dari hasil deskripsi data yang menyatakan skor tertinggi diperoleh dihari terakhir perlakuan yaitu pada skor rata-rata 58,83, dan perawatan rambut rontok menggunakan buah alpukat dan VCO yang dinilai dari jumlah kerontokan pada rambut dapat dinilai dari hasil deskripsi data yang menyatakan skor tertinggi diperoleh dihari terakhir perlakuan yaitu pada skor rata-rata 58,67. 


\section{Simpulan}

Perawatan rambut rontok tanpa penggunaan masker rambut (hair mask) buah alpukat dan VCO pada kelompok kontrol (X0) tidak ada perubahan yang signifikan, dilihat dari hasil olahan data mulai dari perlakuan pertama (pretest) menunjukkan rata-rata 86 hingga perlakuan ke 12 (posttest) menunjukkan rata-rata 80,50.

Perawatan rambut rontok dengan menggunakan masker rambut (hair mask) buah alpukat pada kelompok eksperimen 1 (X1) dengan frekuensi 2 kali 7 hari terdapat perbedaan yang signifikan, dilihat dari olahan data mulai dari perlakuan pertama (pretest 86,7) hingga perlakuan 12 (posttest 60,50), pada indikator kerontokan rambut terdapat perubahan yang signifikan. Dari hasil olahan data pada kelompok eksperimen 1 menunjukkan rata-rata pretest 86,7 menjadi posttest 60,50 .

Perawatan rambut rontok dengan menggunakan masker rambut (hair mask) VCO pada kelompok eksperimen 2 (X2) dengan frekuensi 2 kali 7 hari terdapat perbedaan yang signifikan, dilihat dari olahan data mulai dari perlakuan pertama (pretest 87,3) hingga perlakuan 12 (posttest 58,83), pada indikator kerontokan rambut terdapat perubahan yang signifikan. Dari hasil olahan data pada kelompok eksperimen 2 menunjukkan rata-rata pretest 87,3 menjadi posttest 58,83 .

Perawatan rambut rontok dengan menggunakan masker rambut (hair mask) buah alpukat dan VCO pada kelompok eksperimen 3 (X3) dengan frekuensi 2 kali 7 hari terdapat perbedaan yang signifikan, dilihat dari olahan data mulai dari perlakuan pertama (pretest 87) hingga perlakuan 12 (posttest 58,67), pada indikator kerontokan rambut terdapat perubahan yang signifikan. Dari hasil olahan data pada kelompok eksperimen 3 menunjukkan rata-rata pretest 87 menjadi posttest 58,67.

Terdapat perbedaan rata - rata keempat kelompok, dengan hasil olahan uji duncan dapat dilihat perbandingan hasil rata-rata posttes pada setiap kelompok yaitu kelompok kontrol memiliki rata-rata postest $(80,50)$, kelompok eksperimen 1 memiliki rata-rata postest $(60,50)$, kelompok eksperimen 2 memiliki rata-rata postest $(58,83)$, dan kelompok eksperimen 3 memiliki rata-rata posttest $(58,67)$. Dari keempat perbandingan rata-rata posttest keempat kelompok dapat dilihat kelompok eksperimen 3 memiliki ratarata posttest terbesar $(58,67)$ yang berarti penggunaan masker rambut (hair mask) buah alpukat dan VCO lebih efisien digunakan dengan frekuensi pemakaian 2 kali 7 hari.

\section{Saran}

Bagi Jurusan Tata Rias dan Kecantikan, hasil dari penelitian ini dapat menjadi masukan pengetahuan untuk mata kuliah yang berhubungan dengan perawatan rambut.

Bagi Mahasiswa Program Studi D4 Pendidikan Tata Rias dan Kecantikan, hasil penelitan ini dapat menjadi pengetahuan dan acuan untuk penelitian selanjutnya.

Bagi responden yang cenderung memiliki rambut rontok dapat memanfaatkan alpukat dan minyak kelapa murni (VCO) sebagai bahan hairmask tradisional untuk perawatan rambut rontok.

Hasil penelitian ini diharapkan dapat memberikan inspirasi dan motivasi bagi peneliti selanjutnya.

\section{DAFTAR PUSTAKA}

Andi, Samson. 2013. Penggunaan Buah Alpukat Untuk Rambut. Bogor: Gramedia.

Alamsyah, A.N. 2005. Virgin Coconut Oil: Penakluk Aneka Penyakit. Bogor: Argo Media Pustaka.

Arikunto. 2010. Prosedur Penelitian: Suatu Pendekatan Praktek. Jakarta: Rineka Cipta.

This is an open access article distributed under the Creative Commons 4.0 Attribution License, which permits unrestricted use, distribution, and reproduction in any medium, provided the original work is properly cited. 02017 by author and Universitas Negeri Padang. 
Dalimartha S. 1998. Atlas Tumbuhan Obat Indonesia. Jilid 1. Jakarta: Trubus.

Lismawati RST, Rostamailis, \& Yuliana. 2013. Pengaruh Pemanfaatan Sari Seledri (Apium Graveolens) Terhadap Penyembuhan Ketombe Kering. Program Pendidikan Tata Rias dan Kecantikan UNP. 2 (1):114.http://ejournal.unp.ac.id/index.php/jhet/article/view/1027/864 (diakses tanggal 10 Juli 2019)

Lufri,M.S. 2007. Kiat Memahami dan Melakukan Penelitian. Padang: UNP Press.

Nurlaili. 2013. Dasar Kecantikan Rambut 1. Padang: Kementrian Pendidikan dan kebudayaan Direktorat Pembinaan Sekolah Menengah Kejuruan.

Pusponegoro, Erdinan H.D. 2002. Kerontokan Rambut Etiopatogesis. Kelompok Studi Dermatologi Kosmetik.

Rahmadani, Hayatunnufus, \& Yuliana. 2012. Pengaruh Pemanfaatan Jeruk Nipis Terhadap Penyembuhan Ketombe Kering Dikulit Kepala. Program Pendidikan Tata Rias dan Kecantikan UNP. 1 (1): 1-13. http://ejournal.unp.ac.id/index.php/jhet/article/view/519/439 (diakses tanggal $10 \mathrm{Juli}$ 2019)

Rostamailis, dkk. 2005. Perawatan Badan, Kulit dan Rambut. Jakarta: PT. Rineka Cipta.

Rostamailis, dkk. 2008. Perawatan dan penataan Rambut. Padang: UNP Press.

Rostamailis, dkk 2009. Tata Kecantikan Rambut. Jakarta: Direktorat Pembinaan Sekolah Menengah Kejuruan.

Simons, 2004. Kecantikan Sejati Anda: Perawatan Rambut.Jakarta: PT Gramedia.

Tranggono, Retno, Iswari. 1992. Kiat Apik Menjadi Sehat dan Cantik. Jakarta: PT. Gramedia.

Tranggono, Retno, Iswari. 2007. Buku Pegangan, Ilmu Pengetahuan Kosmetik. Jakarta: PT. Gramedia. 